\title{
DEVELOPMENT TRENDS OF CLEANER PRODUCTION IN LATVIAN INDUSTRY
}

\author{
N. Vanaga \\ Centre for Environmental Science and Management Studies \\ University of Latvia
}

\section{ABSTRACT}

This paper describes the division working with pollution prevention, waste minimization and clean technology at the CESAMS LU, the development of industrial policies and administration in Latvia, Cleaner production activities in Latvia, cooperation environmental management resarch experiences. In detail are mentioned the Latvia Pollution Pollution Prevention Centre.

The aim of the Pollution Prevention Centre is to raise environmental awareness in Latvian industries. Other activities focus on energy saving and clean technology.

\section{INTRODUCTION}

Waste impact on environment is one of the priority environmental problems in Latvia. The amount of household waste is increasing. Waste storage sites are significant sources of localised water, air and soil pollution. Uncontrolled waste dumping in the territory of Latvia is serious concern. It pollutes forests, degrades landscapes and creates a lot of illegal local waste dumps containing wastes of unknown composition and origin [9].

There are many causes of problems connected with waste management. The most significant of them can be recognised as:

- lack of policies for waste minimisation and reuse;

- underdeveloped waste management system and a lack of associated infrastructure;

- heritage of a socialist national economy in production, agriculture and municipal systems. 
- the conception of the pollution prevention and waste minimisation has not been developed and worked out in practice.

The term cleaner technology has become more and more common in the industrial sector, but not widely in Latvia yet. Authorities and consumers throughout the world are putting increased pressure on companies making them focus on minimising their utilisation of resources and reducing environmental impacts from production and products. In order to make environmental analysis on a solid economic foundation more and more Western companies introduce environmental management systems which are still unknown in Latvia, except first two companies acquiring ISO 9001 standard.

In the period of the economical reconstructuring there is high need for development of environmental management understanding and systems in Latvia which can be implemented by different national consultancy experts (state/ private) having competitive advantage as well as the co-operation with the foreign companies/ academics. Direct industry-industry co-operation, both national and international, shall be growing. The role of environmental management research and training/ education cannot be over estimated [10].

Based on separate activities in 1996 at the Centre for Environmental Science and Management Studies was established the division working with pollution prevention, waste minimization and clean technology. The division consists of the experts working in the field of process technology, waste, industry, environment and business management. The division was established with the aim to create a long term unit of the experts with various backgrounds capable to develop research and prepare training programmes, to carry out and implement the projects concerning pollution prevention, clean technology, waste minimisation and do services [9].

The division is working out database of industrial enterprises, including information on environmental indicators (water, energy, transport, emission, waste, heavy metals, etc.). [6] Impartial advice and guidance in matters relating to waste minimisation, pollution prevention, cleaner technology, environmental management could be also given. To improve the services, division has a close co-operation with selected specialists and consultants in Latvia. The following services can be provided by division [9]: assistance in getting loans and grants for industrial environmental projects, training of local consultants, work with industrial enterprises staff and environmental managers, serving bridge among industries, local authorities, legislators and public, implementation of Life-Cycle analysis, cooperation with foreign environmental organisations and projects, developing and introducing of waste minimisation programmes for universities and technical colleges. 


\section{DEVELOPMENT OF INDUSTRIAL POLICIES AND ADMINISTRATION}

During the last years the development of industry in Latvia has undergone a number of quite considerable changes, but historical experience of the other countries proves that enterprises and industrial branches need certain economic preconditions being unchangeable for a longer period of time, so to be able to manage appropriate production activities as well as become able to compete in the international market [1].

While the state control-command system in Latvia the industrial policies were implemented by the State Planning Committee and the Ministry of Industry until 1989. During the period from 1989 till 1993 the Ministry of Industry was merged with the Ministry of Energy what does not lead to the national programme for development of industry being not worked out. In the meantime the manufacturers themselves established different organisations - branch unions, etc., e.g., executive directors of 26 largest enterprises established the Union of Directors, though their activities were rather weak and the dialogue with the government was not mutually beneficial. After the national elections in 1993 the functions of the Ministry of Industry were passed to the Ministry of Finance and Ministry of Economy. There are ministers in Latvia responsible for different branches of national economy, like forestry, agriculture, communications, environment, and the Prime Minister has a counsellor on industrial matters.

The declaration made by the Council of Ministers (accepted by the Parliament in 1992) stated four priorities of structural industrial policy, one of them being the development of scientifically and technologically capacious industries. This document stipulated that a new conception of Latvian industry should be worked out. This order was revised by the Ministry of Economy and the priority was given to the promotion of export, financial market of capital and privatisation. [1.5]

The newly adopted regulations of goveming parties coalition in autumn 1994 among the priorities in tasks of the new government named the promotion of industry. As the result the Department of Economic Policy was founded within the Ministry of Economy. The goal of the Department is to work out the policy of industry development, irrespective of the form of ownership, without a straight interference with its economic activities. [2] The main tasks stated including environment related ones were the following:

- to form mechanisms in order to put into practice the priorities of industrial branches;

- to promote the development and operation of "ecologically clean" enterprises and enterprises expending the local resources;

- to work on solving environmental problems together with other state institutions;

- to create the necessary conditions for development of industrial branches and enterprises; 
- to secure the development of nationally important industrial branches and enterprises with the corresponding policy of investments.

In order to enhance the privatisation process in Latvia, on April 1994, the Government established the non-profit state owned joint stock company "Privatisation Agency" (PA). Existence of a professional institution solely responsible for privatisation was considered to be of vital importance, given that many problems had previously arisen during the evolution of the Latvian privatisation programme.

By the end of the first half of 1998 the privatisation programme will be concluded in principle and will contribute to the new Government's stated objective to complete the transformation of the Latvian economy.

Since the approval of the present Government in November 1995 the reform process speeded up. Latvia is undergoing a successful process of reform which makes the country a full participant of the European economic integration process and leads to a free market based on private initiative. By now, the share of the private sector has reached $65 \%$ of the GDP, and as further privatisation, this proportion will continue.

A very promising example is the quite recently opened Pakenso Baltika Corrugated Cardboard Plant in Riga. The Finnish company has privatised one unfinished enterprise building in February 1995, and by now, 12 million US dollars have been invested in this plant, which is one of the largest foreign investments in Latvia[2].

Among the industrial sectors to remain stable or even increase productivity are the industries of machine building, light industry (include textile), manufactoring of wood and wood products processing and agro-food industries.

In general, the characteristics of environmental problems related to the industrial sectors( that is chemical composition, eco-toxicity, health impact, etc.) have not changed significantly during the last 4 to 6 years. Only, the volume of production has been reduced during the last years, and so, correspondingly, has the volume of produced pollution. As the production increases, it is likely that the level of pollution and waste generation will increase.

\section{CORPORATE ENVIRONMENTAL MANAGEMENT RESEARCH EXPERIENCES}

In the framework of its research activities CESAMS has produced the Latvian report on environmental impact assessment titled "Screening and Quality Control in the EIA in Latvia" in the framework of project "The Baltic-Nordic-Polish Cooperation on EIA" [7], report "Environmental Improvements in Latvian Industrial Enterprises" financed by the European Union PECO programme [1] and others, and there are still on-going research activities carried out in the field of waste management and waste-free technologies, energy management, environmental policy. 
Research includes also sustainable development projects in Latvian local authorities; social impact of energy consumption; public participation, etc. There are under development research and training programmes on environmental impact assessment (EIA) and environmental auditing (EA) in Latvia based on train-thetrainers scheme and know-how transfer and adjustment. The Centre has worked out various projects financed by the World Bank, the EU, the UNESCO, IUCN, etc.

Most thorough investigations and studies of preconditions and possibilities of environmentally friendly industrial activities was done in Latvia by the network research project "Environmental Improvements in Latvian Industrial Enterprises".

The project was worked out by the Centre for Environmental Science and Management Studies in the EU framework programme of the co-operation in science and technology with Central and Easter European countries, co-ordinated by the Free University Berlin.

The project had the following stages: fact founding mission-screening (97 enterprises) and detailed studies of specific enterprises (3 enterprises), as well as preparation of the final proposals for industries, local self-governments and the Ministry for Environmental Protection and Regional Development. The outcome of the project can be formulated as [1]:

- a database about the profiles of companies, including available information about the environmental indicators;

- screening report about the environmental impact in Latvian industry (main Report);

- policy papers for governmental institutions (enclosed in conclusions of report and were presented and discussed during the meeting for preparation of Latvia National Environmental Policy Plan);

- discussions and workshop with industry and representatives of separate companies about the findings organised together with US AID supported World Environmental Centre Latvian office).

The presented research has been directed not only to analysis of a separate industrial enterprises or a separate industrial branch, but it was tended to a wider analysis of general conditions. In the course of research made in enterprises it was failed to find significant factors, reasons or motivation directed to a environment-protective attitude, to changes in manufacturing processes or economy of a raw material. Next excerpts from the research results are also not very encouraging [1].

Analysis proves that state environmental structures and administrative, legislative, economic and other instruments are now in their initial stage, they are tended to specific environmental problems and are directed towards understanding of consequences. In fact, it can be assessed as a kind of control system which on the one hand has: 
- high level of environmental institutions;

- highly developed "end of pipe" control and data collecting system;

- comparatively good legal base;

- active participation in internationally important conventions.

At the same time this is a system which:

- has no political, strategic and action plan, no fixed environmental protection priorities on local, regional and international scale;

- no fixed plans or suggestions for regional and national development;

- no suggestions either on integration of environmental topics in other national economy sectors and branches or structural changes in administration and production;

- no influence on public and NGO, education and re-training is not included in time-schedule of activities; no public relations and as a result - no participation.

- no signals to start the dialogue between control institutions and polluter and the victims of pollution, etc.

All together it demonstrates limited usage of classical environmental policy instruments for improving the environmental conditions and "pressing' applied to producers to move to "greening" dimension. Several positive examples found during our research proves the extremely influential role of a separate personalities in production administration. In reality the news of bad experiences usually spread much faster than news on technical or social innovations for environmental protection. Certainly high importance became the involvement of public and polluter in an administrative decision taking procedure. A lot should be done to develop influence and responsibility of local governments.

In order to achieve environmental success in production the following recommendations are necessary [1]:

- existing and planned environmental policy elements from the Ministry of Environmental Protection and Regional Development (MEPRD) should be integrated in other sectorial policies;

- during the administrative structural changes of Latvian production and service sectors environmental issues must be transformed from status of supplementary (decorative) elements or semi-legal limitations to active factor of structural changes themselves;

- the base of legislation should be developed from administrative and controlling instruments (restrictions and penalties) to instruments of agreements, management and development;

- legislation base has to be developed into subordinated regulations made coordinating with the analogues of our neighbourhood countries; 
- state institutions should transform the existing practise from inspection and "end-of-pipe" control into consultancy, assistance and the assessment of pollution source;

- it is absolutely necessary to support separate "key" personalities dealing with environmental improvements in "successful enterprises". Enterprises should be supported by environmental authorities. the easiest way is the announcement through mass media and individual reimbursement of taxes.

The research activities of the CESAMS are based on information about the technology and production of Latvian industrial enterprises, industrial pollution, i.e., composition of waste water pollution, as well as environmental protection activities. The research is intended to be continued in relation to the waste management in local authorities.

\section{CLEANER PRODUCTION ACTIVITIES IN LATVIA}

One of the so far most successful greening of industry non-governmental activity in Latvia was done by World Environment Centre (WEC). The establishment of the Pollution Prevention Centre (PPC) in Latvia in attempt both to replicate these technical accomplishments in the large number of local businesses that have not yet benefited from this type of assistance and to demonstrate the validity of pollution prevention as an environmentally synergistic concept [8]

LPPC has followed a consistent strategy to raise awareness among Latvian industries about the economic benefits of waste minimisation and translated and disseminated technical information on the cleaner technologies at the special experience exchange seminars. As the result of these activities two local companies DauER and Lokomotive (both from Daugavpils) have purchased from their own sources powder coating lines to replace old electroplating and painting processes for environmentally friendly. Two other companies Rebir (Rezekne) and Daugavpils Driving Chains Plant are planning to make the same improvements;

WEC training workshops and work with US experts was organised to improve skills and capabilities of both PPC's and local consultants as well as waste minimisation idea spread through seminars, flyers, brochure: Economic and Environment Benefits of Industrial Waste Minimisation in Estonia, Latvia and Lithuania [3] in English and Latvian and a supplementary video describing 11 projects in Latvian, English and Russian;

Great importance should be recognised for initiating outreach activities to other donors and international organisations to solicit support: OECD, UNIDO, INEM, REC, Norwegian CPC, etc., as well as increasing development of co-operation with Pollution Prevention Centres in other Baltic States and further afield [7].

Recently there are going on several new activities in the field. So CESAMS started to co-operate with Danish EPA sponsored three-year-long cleaner technology project for Latvian industries" Capacity Building for Cleaner Technology in Latvia", which involves three companies from three industrial branches. Three local consultants working together now with Danish experts, the results of 
implementation will be used as training materials for further in-service training and for university students.

Worth to mention is the waste minimisation project in Zunda, where activities were carried out by the Danish consultants, with help from the local consultant and in co-operation with the enterprise [4]. Also the Riga City Environmental Protection Board was involved with the selection of the industry and discussion regarding the scope of the project and the methodology.

The five air-mix systems were installed in the last year and the company Zunda began reconstructions to adopt the air-mix system. The companies Zunda and Carl Bro Energy \& Environment a/s agreed that Zunda should start implementing an air monitoring programme, including, the reduction of the VOC emission [4].

B y the assistance of the Dutch government there are also other similar activities particularly with energy saving activities in agrofood industries realised by private consultancies from both countries.

Unfortunately due to difficult financial conditions of Latvian economy-intransition and financial possibilities, (non)existing legal (environmental) requirements and level of awareness of industry decision makers local support of cleaner production activities as well as functioning of facilities like LPPC is very limited.

\section{CONCLUSIONS}

Concluding this overview paper of corporate environmental management developments might be recognised that during last years has been done considerable quality and amount of activities both top-down and, especially, bottom-up ones to facilitate cleaner production understanding and realisation. Particularly several "success-story" development projects shall be mentioned as well as industries targeted research and education/ training programmes which in most of the cases have been realised in co-operation and by financial and professional assistance with West-European and USA partners. Experiences adjusted and original ones further elaborated might be supported by capacity building and particularly institutional strengthening developments in Latvia.

\section{REFERENCES}

1. Seglins V., Vanaga N. (1994) - Research project "Environmental Improvements in Latvian Industrial Enterprises". Report. University of Latvia, 90p.

2. Journal "Business with Latvia", No.1-12, 1994, No.1-12, 1996

3. "Economic and Environmental Benefits of Industrial Waste Minimisation in Estonia, Latvia and Lithuania" (1996) - World Environmental Centre, 141 p.

4. "Solid Waste Demonstration Project in Riga, Latvia", Carl Bro, a/s Environment. Report. 1995 
5. Vanaga N. (1994) - Prospects for Cleaner Production in Latvia, Proceedings of UNEP Seminar "Introducing Cleaner Production in Eastern Europe", Kaunas, pp.73-78

6. Sile S. (1995) - Cleaner technology, pollution prevention in the production process. Acta Universitatis Latviensis, No.601 - Environmental Science and Management, pp.64-66

7. "Business and Environment", International Conference, Rìga, Latvia, 1996. Conference Recommendations

8. N.Ladutko (1996), Latvian Pollution Prevention Centre, Pamflet

9. Waste Minimisation and Management Division. Pamphlet. (Sile, U. Blumberga - eds.),1996

10. Emsteins R., Vanaga N. (1996) - Environmental Management Research and Education for Greening Inadustry in Latvia, Report at the International Research Conference"Global Restructuring: A Place for Ecology?", Heidelberg,24-27 November, Newsletter No3. 